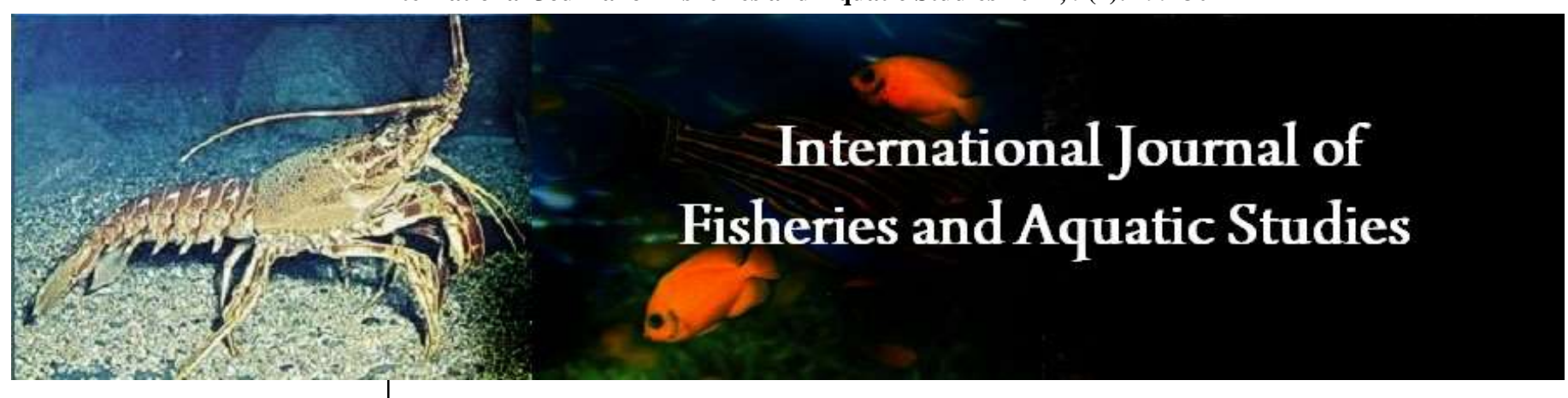

E-ISSN: 2347-5129

P-ISSN: 2394-0506

(ICV-Poland) Impact Value: 5.62

(GIF) Impact Factor: 0.549

IJFAS 2021; 9(1): 299-302

(C) 2021 IJFAS

www.fisheriesjournal.com

Received: 12-11-2020

Accepted: 16-12-2020

Izza Mahdiana Apriliani

Department of Fisheries, Faculty

of Fisheries and Marine Science,

Universitas Padjadjaran,

Indonesia

\section{Herman Hamdani}

Department of Fisheries, Faculty of Fisheries and Marine Science,

Universitas Padjadjaran,

Indonesia

\section{Achmad Rizal}

Department of Fisheries, Faculty of Fisheries and Marine Science,

Universitas Padjadjaran,

Indonesia

Lantun Paradhita Dewanti

Department of Fisheries, Faculty of Fisheries and Marine Science,

Universitas Padjadjaran,

Indonesia

\section{Condition of shrimp commodity capture fisheries in pangandaran regency, West Java}

\author{
Izza Mahdiana Apriliani, Herman Hamdani, Achmad Rizal and Lantun \\ Paradhita Dewanti
}

DOI: https://doi.org/10.22271/fish.2021.v9.i1d.2415

\begin{abstract}
The high potential of capture fisheries makes Pangandaran have abundant fishery resources. One of the excellent commodities in Pangandaran is shrimp and is an economic source for fishermen. This research was conducted to see the condition of shrimp commodity capture fisheries in Pangandaran Regency. The research was carried out in August-October 2019 at Pangandaran Regency Waters with the main focus on shrimp. The method used in this research is the case study method. Data used consists of primary data and secondary data obtained from the local department. The research results shows that the fishing gear used by Pangandaran fishermen to catch shrimp is 459 units of bottom gill nets, 315 units of trammel nets, 25 units of danish seine, and 27 units of beach seine. The fishing vessels which are mostly operated by fishermen in Pangandaran Regency is 1919 types of fishing vessels with a size of <5 GT. The fishing vessel used to catch shrimp is a type of outboard motorboat. Most of Pangandaran people work as a fishermen. Fishermen make shrimp their main catch target with commodities that include jerbung shrimp (Penaeus merguiensis), dogol shrimp (Metapenaeus monoceros), krosok shrimp (Parapenae sculptilis), rebon shrimp (Mysis relicta) and guava shrimp (Metapenaeus lysianassa). The shrimp commodity that produced the highest amount of catches was rebon shrimp with a total production of 248,365.74 in 2018.
\end{abstract}

Keywords: Fishing gear, fisherman, pangandaran, shrimp

\section{Introduction}

Pangandaran waters have large enough potential for marine and fisheries resources. This is indicated by the value of capture fisheries production at Pangandaran Regency in 2016 which was recorded of 1.049,49 tons based on data from Pangandaran Regency Marine Fisheries, and Food Security Service. Most of the catch in Pangandaran Regency is dominated by jerbung shrimp, lobster, sea catfish, black pomfret, white pomfret, red snapper, white snapper, long jawed mackerel, tuna fish, spanish mackerel and sword fish [1]. One of the excellent commodities in Pangandaran is shrimp. The location of Pangandaran sea which is directly opposite the Southern Java waters makes shrimp catches very abundant. The distribution of shrimp in the southern waters of Java is along the coast of Pangandaran, Ciamis, Penyu Bay, Cilacap to South Yogjakarta and Pacitan, East Java ${ }^{[2]}$.

Fisheries in Pangandaran Regency are included in small scale fisheries. In addition to being characterized by technology and relatively small business capital, small-scale fisheries are also characterized by various types of fishing gear used and the catch that is caught ${ }^{[3]}$. The fishing gear used by Pangandaran fishermen to catch shrimp includes beach seine, gillnet, trammel net and danish seine. Danish seine in Indonesia called dogol fishing gear. Dogol that operating in Pangandaran Regency are classified as a bag trawl fishing gear which catch shrimp as the main catch ${ }^{[4]}$. Judging from the construction, this fishing gear is included in the mini bottom trawl group. In principle, mini bottom trawl consists of cod end, body, wing and otter board ${ }^{[5]}$. Most of the fishing vessels used by Pangandaran fishermen are outboard motorboats that use outriggers. The fishing ground areas where Pangandaran fishermen operate are located around Pangandaran Bay, Parigi, Karapyak, Nusakambangan, and Cilacap waters ${ }^{[6]}$.

Shrimp is a leading commodity of fishery products and in Indonesian waters it has more than 83 types of shrimp ${ }^{[7]}$. The increase in shrimp production has provided an increase in foreign exchange from non-oil and gas exports, because shrimp has been able to show its dominance as one of the mainstay export commodities in the world market ${ }^{[8]}$.
Corresponding Author: Izza Mahdiana Apriliani Department of Fisheries, Faculty of Fisheries and Marine Science, Universitas Padjadjaran Indonesia 
Shrimp produced in Pangandaran Regency comes from two sub-sectors, namely through aquaculture and capture fisheries. Dogol shrimp, jerbung shrimp, guava shrimp are examples of shrimp commodities that are marketed in almost all restaurants in Pangandaran [9]. The potential of Pangandaran Regency is the basis that shrimp production can contribute to the economy in Pangandaran Regency. One of the economic sources of Pangandaran fishermen is the large demand for shrimp.

The large demand for shrimp requires scientific information and data on potential shrimp resources that are complete, up to date, and sustainable from Pangandaran waters. Lack of information regarding the shrimp commodity from the capture fisheries sub-sector, it is necessary to research on the condition of the shrimp commodity capture fisheries in Pangandaran. This research can be used as a basis for further research on shrimp resources in Pangandaran Regency.

\section{Materials and Methods}

This research was carried out in August-October 2019 at Pangandaran Regency, West Java (Figure 1) with a focus on shrimp commodity. This research was conducted using a case study method. A case study is a series of scientific activities carried out intensively, in detail and in depth about a program, event and activity, whether at the level of an individual, group of people, institution or organization to obtain in-depth knowledge of the incident ${ }^{[10]}$. The data collected includes primary data and secondary data.

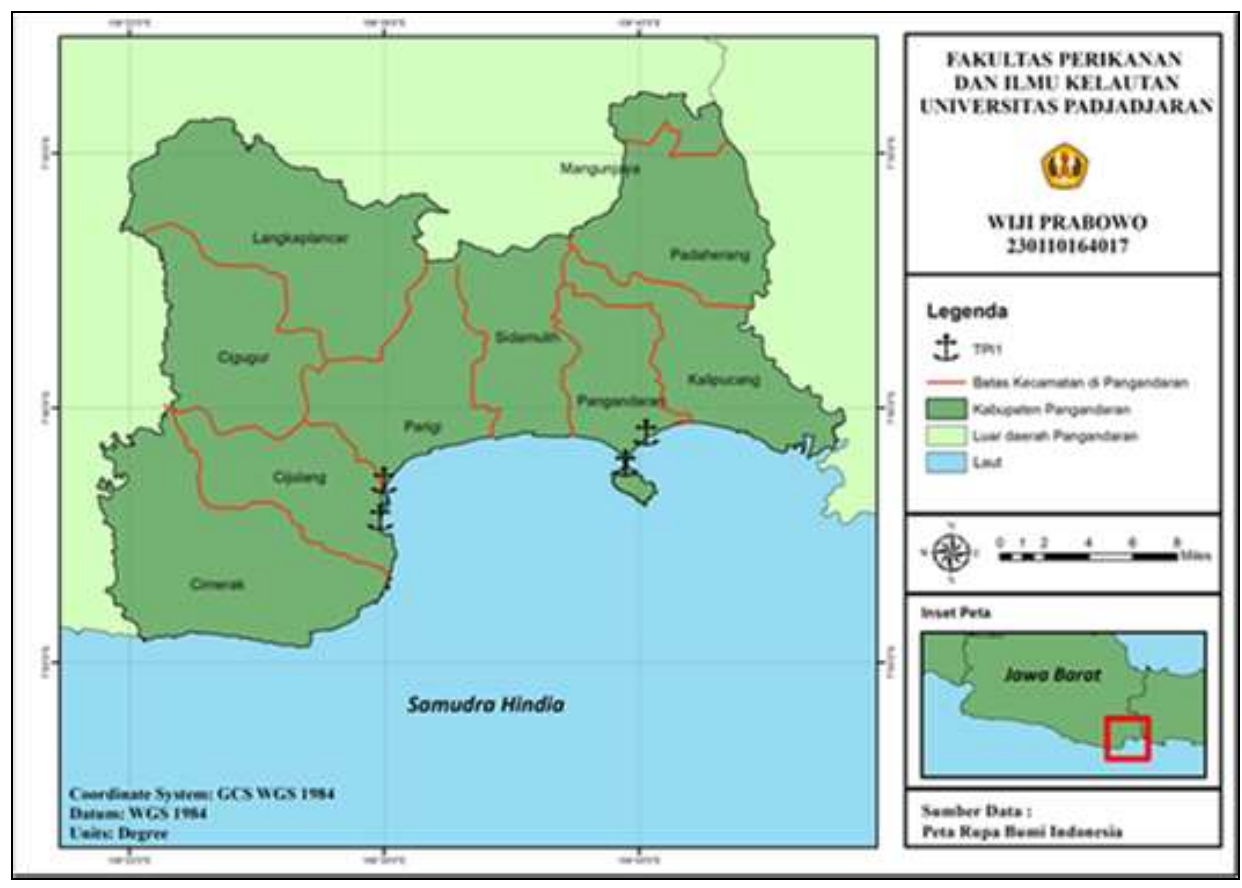

Fig 1: Map of Research Location

Primary data collected directly in the field during the study were shrimp fishing units in Pangandaran Regency which consisted of fishing gear, fishing vessels and fishermen. Secondary data used are data on the amount and types of fishing gear used by fishermen to catch shrimp, amount of fishing vessels, amount of fishermen and data on shrimp production in Pangandaran Regency.

The data obtained were analyzed by descriptive analysis. Descriptive is a study to find facts with the right interpretation. The purpose of descriptive research is to make descriptions in a systematic, factual, and accurate about the facts, characteristics and relationships between the phenomena being investigated ${ }^{[11]}$.

\section{Results and Discussion}

Geographically, Pangandaran Regency is at coordinates $108^{\circ}$ 41 '- $109^{\circ}$ East Longitude and 070 41'- 070 50' South Latitude. When viewed from the map, Pangandaran Regency is bordered by Ciamis Regency and Banjar City in the North, Cilacap Regency in the East, the Indian Ocean in the South, and Tasikmalaya Regency in the West. Based on the Regulation of the Minister of Marine Affairs and Fisheries No.01 / MEN / 2009 concerning the Republic of Fisheries Management Areas Indonesia, Pangandaran is one of the areas included in the Fisheries Management Area zone or WPP-RI 573, covering the Indian Ocean south of Java to the south of Nusa Tenggara, the Sawu Sea, and the West Timor Sea. There are 10 important commodities with the highest production value including shrimp, red snapper, white snapper, grouper, black pomfret, white pomfret, spanish mackerel, word fish, cabuk and tuna mackerel ${ }^{[12]}$.

\subsection{Shrimp Fishing Gear}

The fishing gear used in Pangandaran Regency is very diverse. The fishing gear used by fishermen to catch shrimp in Pangandaran Regency is presented in Table 1.

Table 1: Types of fishing gear operating in Pangandaran Regency

\begin{tabular}{|c|c|c|}
\hline No & Type of Fishing Gear & Total (Units) \\
\hline 1 & Trammel Net & 315 \\
\hline 2 & Danish Seine & 25 \\
\hline 3 & Beach Seine & 27 \\
\hline 4 & Bernong Net (gill net) & 459 \\
\hline
\end{tabular}

Source: DKPKP Capture Fisheries Sector in Pangandaran Regency in 2019

Based on the data presented in Table 1, the fishing gear that is most widely used to catch shrimp is the bernong net fishing gear with a total of 459 units and the least is the danish seine fishing gear with a total of 25 units. Gill net that is operated in Pangandaran Regency is a type of bottom gill net because it catches demersal fish, one of them is shrimp. Bernong net is 
local name of bottom gill net in Pangandaran. Gill nets are widely used by fisherman because gill nets are environmentally friendly fishing gear ${ }^{[13]}$. The lack of fishing gear operated in Pangandaran was caused by tsunami disaster in Pangandaran, so that all fishing gear was damaged and lost [14]. One of effort to re-stabilize the conditions of capture fisheries in Pangandaran, the local government provides assistance to fishermen in the form of gillnet fishing gear, and the others fishing gear.

\subsection{Shrimp Fishing Vessel}

Fishing vessels is a tool used to support fishing activities so that it can help fisheriman to obtain maximum catch. The fishing vessel operating in Pangandaran Regency is divided into several groups according to the size of Gross Tonnage (GT). The size classification of fishing vessels operating in Pangandaran Regency can be seen in Table 2 below.

Table 2: Fishing vessels in Pangandaran Regency

\begin{tabular}{|c|c|c|c|c|c|c|c|}
\hline \multirow{2}{*}{ No } & \multirow{2}{*}{ Sub-district } & \multicolumn{5}{|c|}{ Fishing Vessel } & Total \\
\cline { 3 - 8 } & & $\mathbf{5}$ GT & $\mathbf{5 - 1 0 ~ G T ~}$ & $\mathbf{1 0 - 2 0}$ GT & $\mathbf{2 0 - 3 0}$ GT & $>\mathbf{3 0}$ GT & \\
\hline 1 & Cimerak & 93 & - & - & - & - & 93 \\
\hline 2 & Cijulang & 284 & 1 & 2 & 1 & 1 & 289 \\
\hline 3 & Parigi & 307 & - & - & - & 1 & 308 \\
\hline 4 & Pangandaran & 1081 & - & 1 & 1 & 6 & 1089 \\
\hline 5 & Kalipucang & 154 & - & - & - & - & 154 \\
\hline & Total & $\mathbf{1 9 1 9}$ & $\mathbf{1}$ & $\mathbf{3}$ & $\mathbf{2}$ & $\mathbf{8}$ & $\mathbf{1 9 3 3}$ \\
\hline
\end{tabular}

Source: DKPKP Capture Fisheries Sector in Pangandaran Regency in 2019

The fishing vessels operating in Pangandaran waters are dominated by size <5 GT with a total of 1,919 units, this is due to the limited capital owned by fishermen and the lack of skills of fishermen in operating fishing vessels. The fishing vessels most commonly used in Pangandaran to catch shrimp are outboard motorboats. The outboard motorboat in Pangandaran made from fiber glass which uses a type of outboard engine with a power of $15 \mathrm{PK}$. The boat has a total length over all (LOA) of 7-11, 5 meters, breadth (B) 0.8-1.2 meters, and depth (D) 0.7-1.5 meters.

\subsection{Fisherman}

According to Law No. 45 of 2009 about Fisheries, fishermen are people whose livelihoods are fishing. Most of the coastal communities in Pangandaran Regency work as fishermen. Pangandaran has considerable fishery potential, especially for capture fisheries, so that made a livelihood as a fisherman is the main income for people in Pangandaran ${ }^{[15]}$. The diversity of fishermen's resources in Pangandaran. The number of fishermen in Pangandaran Regency can be seen in Table 3.

Table 3: Total of fishermen in Pangandaran Regency

\begin{tabular}{|c|c|c|}
\hline No. & Sub-District & Total of Fisherman \\
\hline 1 & Cimerak & 593 \\
\hline 2 & Cijulang & 627 \\
\hline 3 & Parigi & 764 \\
\hline 4 & Cigugur & - \\
\hline 5 & Langkaplancar & - \\
\hline 6 & Sidamulih & 315 \\
\hline 7 & Pangandaran & 2.207 \\
\hline 8 & Kalipucang & 562 \\
\hline 9 & Padaherang & 14 \\
\hline 10 & Mangunjaya & 2 \\
\hline \multicolumn{2}{|c|}{ Total } & $\mathbf{5 . 0 8 4}$ \\
\hline
\end{tabular}

Source: DKPKP Capture Fisheries Sector in Pangandaran Regency in 2019

Based on Table 3, shows that the largest amount of fishermen are fishermen who come from Pangandaran Sub-district, namely 2.207 people. Fishermen in Pangandaran are classified as traditional fishermen, who only rely on experience without tools in determining the fishing ground area. It is known that fishing activities carried out by fishermen in Pangandaran still use traditional methods inherited by their ancestors, especially in determining fishing ground areas such as seeing the color of the water surface, small ripples, fish jumping, the presence of foam, and seeing the presence of birds at sea ${ }^{[16]}$.

\subsection{Shrimp Catch Production}

Shrimp commodities found in Pangandaran Regency consist of Jerbung Shrimp (Penaeus merguiensis), Dogol Shrimp (Metapenaeus monoceros), Krosok Shrimp (Parapenae sculptilis), Rebon Shrimp (Mysis relicta) and Guava Shrimp (Metapenaeus lysianassa). The production of shrimp catches in Pangandaran Regency in 2018 can be seen in table 4.

Table 4: Shrimp commodity production results in Pangandaran Regency

\begin{tabular}{|c|c|c|c|}
\hline Spesies & Total Production $\mathbf{( K g )}$ & Production Value (Rp) & Price/Kg (Rp) \\
\hline Jerbung Shrimp (Penaeus merguiensis) & 12.092 & 1.791 .108 .950 & 148.000 \\
\hline Dogol Shrimp (Metapenaeus monoceros) & $84.792,10$ & 5.811 .855 .400 & 68.500 \\
\hline Krosok Shrimp (Parapenae sculptilis) & 95.103 & 1.989 .839 .770 & 20.900 \\
\hline Rebon Shrimp (Mysis relicta) & $248.365,74$ & 3.225 .341 .820 & 12.900 \\
\hline Guava Shrimp (Metapenaeus lysianassa) & 288.375 & 4.325 .341 .820 & 25.800 \\
\hline Total & $\mathbf{7 2 8 . 7 2 7 , 8 4}$ & $\mathbf{1 7 . 1 4 3 . 4 8 7 . 7 6 0}$ & \\
\hline
\end{tabular}

Source: Cikidang Fishery Port Profile Data in $2018^{[17]}$ 
Based on Table 4, it shows that total of shrimp production in 2018 produced was quite a lot, reaching $728.727,84 \mathrm{~kg}$ with a production value of $\mathrm{Rp}$. 17.143.487.760. Krosok shrimp, dogol shrimp and jerbung shrimp are included in the economic types of shrimp in Indonesia ${ }^{[18]}$. The amount of shrimp production of guava shrimp and rebon shrimp is more than the other shrimp. This shows that the waters of Pangandaran Regency have very abundant shrimp. The type of catch that is mostly caught on Pangandaran Beach is rebon shrimp as the main catch, which is $411 \mathrm{~kg}$ or $91 \%$ of the total catch ${ }^{[19]}$. In Indonesia, this type of shrimp is one of the raw materials used for making shrimp paste.

The small amount of Jerbung shrimp production is one of the factors that causes the price of jerbung shrimp to be expensive. In addition, the larger of the size, the more of expensive the price. Jerbung shrimp has high economic value, and its production still depends on catch from nature [20]. Indonesia as one of the seven countries that produce jerbung shrimp in the world, even its contribution reaches $82 \%$ (107.000 tonnes in 2015), the highest compared to other countries such as Vietnam, Thailand, Australia, Philippines, Papua New Guinea and Solomon Islands ${ }^{[21]}$.

\section{Conclusions}

Based on the results of the study, that shrimp capture fisheries in Pangandaran Regency was quite large with the commodity type of jerbung shrimp (Penaeus merguiensis), dogol shrimp (Metapenaeus monoceros), krosok shrimp (Parapenae sculptilis), rebon shrimp (Mysis relicta) and guava shrimp (Metapenaeus lysianassa). The fishing gear used to catch shrimp consists of gill net, trammel nets, beach seine and danish seine. Fishing vessels that are widely used to catch shrimp, namely fishing vessels of $<5$ GT.

\section{Acknowledgement}

We would like to thank Wiji Prabowo and Delinda Nirmalasari who have helped in the implementation of this research.

\section{References}

1. DKPKP. Department of Maritime Affairs, Fisheries and Food Security Pangandaran Regency. Fisheries statistics Pangandaran Regency. Annual report, Pangandaran Regency, 2016.

2. Subagyo W. Distribution status of shrimp in southern waters of Java is along the coast of Pangandaran, Ciamis, Penyu Bay, Cilacap to South Yogjakarta and Pacitan, East Java. Dissertation, Bogor Agricultural University, Bogor 2005, 506p.

3. Wiyono ES. Selectivity of garuk fishing gear species in Cirebon, West Java. Bumi Lestari Journal 2009;9(1):6165.

4. Dewanti LP, Apriliani IM, Faizal I, Herawati H, Zidni I. Catch Comparison and Catch Rate of Fishing Gear in Fish Auction Pangandaran. Indonesian Aquatic Journal 2018;3(1):54-59.

5. Ernawati T, Sumiono B. Catching results and catching rate of arad nets (mini bottom trawl) based at TPI Asemdoyong Pemalang. Indonesian Fisheries Research Journal 2010;16(4):267-274.

6. Anas P, Jubaedah I, Dinno S. Sustainable potential of capture fisheries as a result of resource management in Pangandaran Regency. Journal of Fisheries and Marine Education 2016;10(2):88-99.
7. Prasetyo A, Boesono H, Asriyanto. Analysis of the catch of tiger shrimp (Penaeus semisulcatus) on double ring shrimp net based on time differences in Arafura waters. Journal of Fisheries Resources Utilization Management and Technology 2014;3(2):62-71.

8. Syahfdi OF, Siregar MA, Hamid A. Analysis of export market demand for indonesian frozen shrimp products. Journal of Agribusiness North Sumatra 2010;3(2):8-16.

9. Widowati R. Existence of bacteria vibrio parahaemolyticus in shrimp for sale in pangandaran beach eating house. Vis Vitalis 2008;1(1):9-14.

10. Rahardjo M. Case studies in qualitative research. State Islamic University, Malang 2017, 26p.

11. Nazir M. Research methods. Ghalia Indonesia, Jakarta 2017.

12. DKPKP. Department of Marine Affairs, Fisheries and Food Security Pangandaran Regency. Fisheries statistics Pangandaran Regency. Annual report, Pangandaran Regency, 2019.

13. Lisna, Amelia JM, Mia A. Friendly analysis of gill net enviromentally fishing gear in Nipah Panjang Regency, Jambi. Journal of Fisheries and Marine Technology 2018;9(1):83-96.

14. Azam DH. Study on the prospects of post-tsunami capture fisheries at PPI Pangandaran, West Java. Thesis, Bogor Agricultural University, Bogor, 2009.

15. Nurhayati A. Analysis of the sustainable potential of capture fisheries in pangandaran area. Aquatic Journal 2013;4(2):195-209.

16. Firmansyah R, Hasan Z, Afrianto E, Apriliani IM. Mapping of potential fishing ground for sword fish (Trichiurus sp) in Pangandaaran waters, West Java. Airaha Journal 2018;7 (1):006-012.

17. Cikidang Fishing Port. Profile of the center for marine and fisheries at Cikidang Fishing Port Pangandaran Regency. PP Cikidang, Pangandaran, 2018. (Power point delivered by Rukmana, S.St.Pi,).

18. WWF. World Wide Fund for Nature Indonesia. Environmentally friendly shrimp catching using trammel net fishing gears. Graha Simatupang, South Jakarta 2015, 32p.

19. Dwipayana MF, Sunarto, Rostini I, Apriliani IM. Results of floating chart catches with different hauling times on the east coast of pangandaran. Journal of Fisheries and Marine Affairs 2018;9(1):112-118.

20. Kusrini E, Hadie W, Alimuddin, Sumantadinata K, Sudrajat A. Morphometric study of jerbung shrimp (Fenneropenaeu merguiensis) of several populations in Indonesian Waters. Journal of Aquaculture Research and Technology 2009;4(1):15-21.

21. Prastowo BW, Prihutomo A, Bond MM, Penataseputro T, Senggagau B. Anorganic nitrogen control to control toxic $\left(\mathrm{NH}_{3}\right)$ form nitrogen in vaname shrimp (Litoprnaeus vannamei) Farms Using a Combination of Molasses and Probiotics. Journal of Indonesian Aquaculture Fisheries 2018;2(1):13-36. 